\title{
Naming the Combatants of the Colombian Armed Conflict in News Broadcasts: The Discursive Positioning of Journalists
}

\section{Yeny Serrano ${ }^{1}$}

Recibido: 2014-04-08

Enviado a pares: 2014-04-08
Aprobado por pares: 2014-11-18

Aceptado: 2015-04-14

DOI: 10.5294/pacla.2016.19.1.3

Para citar este artículo / To reference this article / Para citar este artigo

Serrano, Y. (Marzo de 2016). Naming the combatants of the colombian armed conflict in news broadcasts: The discursive positioning of journalists. Palabra Clave, 19(1), 57-84.

DOI: 10.5294/pacla.2016.19.1.3

\section{Abstract}

By examining the labels used to refer to the Colombian armed groups in news, this study analyses to what extent news incorporates the war communication $^{2}$ of the armed groups. The analysis of 452 news reports broadcast by national channels shows that most reports are written in a detached manner, suggesting the 'objectivity' of news reporting. Nonetheless, the qualitative analysis shows that this factual and descriptive style hides the subtle discursive bias of news. Thus it is concluded that Colombian media has contributed more to war than to peace building.

\section{Keywords}

journalists' discursive detachment, Colombia, military, guerrillas, paramilitary, war communication (Source: Unesco Thesaurus).

2 The expression 'war communication' refers to the way in which armed groups use communication (public relations, press relations and messages disseminated through the media -media operations-) to conduct war. This study particularly focuses on messages disseminated through the media with the aim to impose a particular frame onto the conflict (Maltby, 2012). 


\section{Nombrando a los combatientes del conflicto armado colombiano en los noticieros: el posicionamiento discursivo de periodistas}

\section{Resumen}

Mediante el examen de las etiquetas utilizadas para referirse a los grupos armados colombianos en las noticias, este estudio analiza en qué medida la comunicación de las noticias de la guerra incorpora a los grupos armados. El análisis de 452 informes de prensa difundido por canales nacionales muestra que la mayoría de informes se escriben de forma independiente, lo que sugiere la "objetividad" de los informes de prensa. No obstante, el análisis cualitativo muestra que este estilo fáctico y descriptivo esconde la tendencia discursiva sutil de noticias. Por lo tanto, se concluye que los medios de comunicación colombianos han contribuido más a la guerra que a la construcción de la paz.

\section{Palabras clave}

Desprendimiento discursivo de periodistas, Colombia, militares, guerrilleros, paramilitares, comunicación de guerra (Fuente: Tesauro de la Unesco). 


\section{Nomeando aos combatentes do conflito armado colombiano nos noticiários: 0 posicionamento discursivo de jornalistas}

\section{Resumo}

Por meio do exame das etiquetas utilizadas para se referir aos grupos armados colombianos nas notícias, este estudo analisa em que medida a comunicação das notícias da guerra incorpora os grupos armados. A análise de 452 relatórios de imprensa difundidos por canais nacionais mostra que a maioria deles é escrito de forma independente, o que sugere a sua "objetividade". Contudo, a análise qualitativa mostra que esse estilo fático e descritivo esconde a tendência discursiva sutil das notícias. Portanto, conclui-se que os meios de comunicação colombianos têm contribuído mais à guerra do que à construção da paz.

\section{Palavras-chave}

Desprendimento discursivo de jornalistas, Colômbia, militares, guerrilheiros, paramilitares, comunicação de guerra (Fonte: Tesauro da Unesco). 


\section{Introduction}

Over the past decades researchers have sought to understand how the military influences journalists, and vice versa; and to what extent and why news could be biased. At the same time, they have been interested in how media frames wars and conflicts (e.g. Allan and Zelizer, 2004; Carruthers, 2011; Dayan, 2006; Hoskins and O'Loughlin, 2010; Schudson, 2000; Tumber and Webster, 2006). Studies on the coverage of the Colombian armed conflict are no exception. Both scholars and journalists in Colombia have criticized the way in which national media cover the armed conflict between the military, paramilitary, and guerrilla groups. Colombian media has been accused of manipulating public opinion. Journalists have been blamed for favouring one or other of the combatants and disrespecting civilian victims by using a framing based on their suffering while offering little understanding of the causes of the conflict and the claims of the armed groups (Bonilla and Patiño, 2001; Correa, 2001, 2008; Flores and Crawford, 2001; López, 2005, 2003; PAN, 2004; Rincón and Ruíz, 2002; Tamayo and Bonilla, 2005; Torres, 2004).

One of the criticisms that concerns the terms used by Colombian journalists to refer to these armed groups and their actions (Flores and Crawford, 2001; Giraldo et al., 2003; Tamayo and Bonilla, 2005). Depending on these labels, journalists and (armed) sources have been accused of spreading the armed groups' propaganda (Giraldo et al., 2003; López, 2011; Rincón and Ruíz, 2002). Speaking of paramilitary and guerrillas groups as 'illegal armed groups' means that the differences between these groups concerning their origins and their political motivations are hidden. Labelling the confrontation between the military, paramilitary and guerrilla groups an 'internal armed conflict' does not have the same implications as labelling it a 'terrorist threat' from some 'delinquent groups without any political motivation' (Samouth and Serrano, 2012).

Most of the previously quoted Colombian studies, which criticise media and journalists, have been conducted with a uni-disciplinary approach that prevents media analysts from taking into account the different variables influencing the form and the content of news in times of war and, more 
specifically, the strategic issues associated with the terms used to refer to the conflict, the groups involved in it, and their actions. Even if the Colombian armed conflict has become one of the main research topics for Communication and Journalism Studies (Bonilla and Tamayo, 2007; Flores and Crawford, 2001; Giraldo et al., 2003; Rincón and Ruíz, 2002; Tamayo and Bonilla, 2005), Psychology (Alzate et al., 2009; Barreto et al., 2009; Tovar et al., 2008), Political Science (Barón, 2001; Estrada, 2004, 2001), Semiotics (Barbero, 2001, 1998) and History (López, 2005, 2003, 2002, 2001, 2000), the contributions of these studies have not been integrated into a single approach. For instance, while historians analyse how media frame the conflict (López, 2003, 2001), their studies do not take into account findings from journalism studies (Rincón and Ruíz, 2002). Those studies have shown that journalists' work is influenced by external constraints (competition between media organizations); not only by professional guidelines (e.g. neutrality, impartiality) as well as media managers' demands.

Thus, one of the contributions of this study is to connect some of the theoretical results from the fields of Communication Sciences, Linguistics, Journalism Studies and Political Psychology studies. For this purpose, the next section proposes a theoretical framework of reporting news in wartimes. In doing so, the aim of this paper is to understand how the war communication of the armed groups affects the news as reported by journalists. In other words, how the coverage of the armed conflict depends not only on media constraints but also on the constraints imposed by the context of war. For this purpose, this study analyses the ways in which the armed groups are named in the news, as well as the legitimacy issues associated with the labels that journalists do or do not adopt from their sources. This paper also examines the discursive positioning that Colombian journalists display in their news in relation to the war communication of armed groups. The notion of 'discursive positioning' refers to the way in which journalists report news in relation to the version provided by sources. The different categories of this positioning are described in the methodology section.

The interest of this study is that it provides useful understanding on how media has covered the conflict for years. In fact, this coverage could 
affect the role of media in peace building and the way they are covering the current peace talks between the government and FARC guerrillas.

\section{Reporting news in war times}

Reviewing and integrating the main results of the literature published about media and the coverage of wars and armed conflicts, researchers have found that this coverage is influenced by three kinds of variables: media, journalistic and war communication variables. Media variables involve the necessity - for media industries - of making a profit while taking care of maintaining credibility (Charaudeau, 2009; McQuail, 2010, chap. 11). Journalistic variables involve the constraints that journalists have to overcome in their professional lives related to the exigencies from media owners (rating and credibility) and the pressure exerted by their sources (Berkowitz, 2009; Carlson, 2009; McQuail, 2010, chap. 12). War communication variables are linked to the fact that in war, armed groups may be one of the principal sources for journalists. When the armed groups' representatives speak to journalists, their motivation is to make journalists talk about the war from their point of view, that is, to impose their own framing for war, to justify their cause, discredit the adversary and to convince politicians and civil population that war is necessary (Hoskins and O'Loughlin, 2010; Keeble, 2007; Maltby, 2012).

When journalists interact with the armed groups or other social actors involved in a conflict, they have to cope with their strategic discourses (Berkowitz, 2009; Carlson, 2009; Hanitzsch, 2007) because these sources are interested in winning a war, not in informing citizens (Barreto et al., 2009; Borja et al., 2008; Maltby and Keeble, 2007; Maltby, 2012, 2010; Rid, 2007). The form and the content of news about an armed conflict or a war thus results from a double framing. ${ }^{3}$ The first results from the strategic legitimizing discourses of sources and the second from journalists. In this sense, news depends not only on media constraints but also reflects

3 The concept of framing refers to interpretative reading when individuals (journalists, sources) talk about a topic. The framing is expressed through the words chosen (at the expense of others) to name and describe topics (Entman, 2010, 1993; Iyengar, 1991; Scheufele, 1999). For instance, the framing given, and thus the meaning suggested, by these two phrases, describing the same situation, is not the same: 'the terrorists assassinated ten innocent civilians' vs. 'ten people died in an attack'. 
the interests of all those who participate in the process of creating it: sources, media owners, audiences (as imagined by the media) and journalists.

This is one of the reasons why part of journalists' work consists of adapting the discourses provided by sources according to journalistic and media standards. These standards are related to the exigencies of credibility and rating and, more specifically, to the 'objective' style given to the news (factual, detached, neutral) (Chalaby, 1998; Schudson and Anderson, 2009). Concerning the way in which journalists adapt these discourses to media standards, it is useful to take into account studies related to the role of the language in the construction of reality. French literature in discourse analysis, presented in the following section, provides a useful approach to the act of naming.

\section{Naming actors and events: the speakers' point of view}

The words used to refer to and describe events and the individuals involved in them are linked to the speakers' point of view, their ideology and the way in which they see 'reality' (Veniard, 2011). Research in linguistics has demonstrated the importance of the act of naming an event or a social actor. The label orientates the way in which the event or social actor is interpreted (Branca-Rosoff, 2007; Moirand, 2009; Siblot, 2007). The groups conducting a war, such as politicians or armed groups, know and are aware of the fact that the terms and the expressions they use to talk to journalists could influence the way they are seen by audiences and whether or not the war is seen as legitimate (Reyes, 2011). For instance, regarding their political motivations, guerrilla groups refer to themselves as 'rebels' or 'insurgents', while their adversary (the military and the Colombian government) seeks to delegitimize these groups with expressions such as '(narco)terrorist'.

\section{Colombian journalists improving the coverage of the conflict}

Colombian journalists are also aware that armed groups have strategic interests when they talk to them (Márquez González, 2003). Therefore many 
journalists in the country have advocated for the necessity of practicing journalism that does not follow and publicise the war lexicon of these armed groups. For the last 25 years, in order to improve news reporting, journalists have taken the initiative in setting professional guidelines for reporting the conflict in a responsible way. These initiatives include writing style guides (Castro et al., 2005; El Tiempo, 2003), signing agreements ("Acuerdo por la discreción," 1999) and organizing trainings and seminars with specialists (MPP, 2006). In these manuals, agreements and trainings, the 'objectivity' of information is a primary goal. However, this kind of initiative is mainly based on a journalistic point of view. Thus, while objectivity is associated with a way of reporting news, involving neutrality, balance and factuality (Chalaby, 1998; Schudson and Anderson, 2009; Tuchman, 1972), in practice the context of war and the strategic aims of those conducting it, who are at the same time sources for journalists, affect the application of objectivity rules. For instance, in Colombia some media owners have decided to support the state because it is the only legitimate actor in the conflict. They put pressure on their employees (journalists) to favour official sources (MPP, 2006; Sierra, 2001). In addition, economic constraints lead media owners to decrease the resources dedicated to covering conflict zones. As a result, working conditions for journalists covering the conflict are precarious. The Colombian government and military do not accept that journalists give the same treatment to the military and guerrillas. ${ }^{4}$ Military officers demand the unconditional support of journalists (Rincón and Ruíz, 2002). Besides this, since 1997, there has been an official guideline preventing journalists from publishing or broadcasting guerrillas' or 'terrorist' groups' press releases. ${ }^{5}$

When Colombian journalists and scholars agree on the idea of reporting in a detached manner and agree not to relay on the war lexicon of the armed groups, they seem to underestimate the context of war in which the reporting of news happens. When journalists state that covering the conflict in an appropriate way consists of consulting diverse and opposite sources and reporting news in a factual and descriptive style that

4 Actually, this topic also emerged during the current peace discussions between the Colombian government and FARC guerrillas.

5 National Television Authority, http://www.antv.gov.co/normatividad/acuerdos/1997/acuerdo_017.pdf 
does not favour any source in particular, they seem to underestimate the constraints imposed by authorities.

Knowing that Colombian journalists have included in their professional guidelines (Castro et al., 2005) the rule of not relaying on the war lexicon of armed groups, this study addresses two main research questions:

RQ1: How do journalists position themselves regarding the war lexicon of the armed groups on which they report?

RQ2: To what extent do journalists distance themselves in their reporting from the nomenclature of the armed groups that could (de)legitimise their reporting?

\section{Methodology}

Given that television is the media with the highest audience ratings in Colombia (CNTV, 2011, 2009, 2005), this study analyses the news stories broadcasted by the four national evening news programs: Telepais and CMs (broadcast by the public network Canal Uno), and Noticias Caracol and Noticias RCN (broadcast by the two private channels). These four news programs were recorded between June 2006 and June 2008. As the media archives of the media in Colombia are not available, the data for this study was collected over a particular period. This implies that the study of a longer period would make it possible to confirm whether the tendencies observed in this study are on-going or not. The following dates were chosen at random: 12 - 15 June 2006; 11 - 15 December 2006; 25 - 29 June 2007; 10 - 14 December 2007 and 16 to 20 June 2008. This period corresponds to the second presidential term of Mr. Uribe whose policy was to strengthen military actions against the FARC. He sought to exterminate the adversary militarily, while presidents before and after him held peace talks with FARC guerrillas.

We selected and transcribed the news stories related to the armed conflict broadcast within the particular timeframe selected for this analysis: 452 in total, which corresponds to 10 percent of all news stories broadcast by 
the four national television news programs. The analysis was conducted in two phases. The first phase determined the sources that journalists tended to use most, and how present and visible each of the armed groups were as sources in the news (the military, paramilitary and guerrillas -FARC and ELN-). The aim of this initial stage was to examine the plurality and balance of sources in order to identify which of the armed groups had more chances of disseminating, through the media, their own labels.

The second phase focused on the 2,624 expressions used to name the armed groups (military: 665, paramilitary: 767 , guerrillas: 1,192 ) in order to determine how these expressions (de)legitimise the armed groups and to what extent journalists are detached from or engaged with these expressions. In this perspective, two categorizations were carried out. In the first, all the expressions were classified depending on the degree of legitimacy they suggested as shown in table 1 :

\section{Table 1. Labels used to name armed groups and their members}

\begin{tabular}{|c|l|}
\hline Category label & \multicolumn{1}{c|}{ Description } \\
\hline Identification & $\begin{array}{l}\text { This category includes the words corresponding to the name of the combatant or the name of } \\
\text { the armed group (e.g. FARC guerrilla, General Freddy Padilla...). }\end{array}$ \\
\hline Negative assessment & $\begin{array}{l}\text { Expressions that discredit the armed group or a combatant (e.g. the terrorist FARC group, the } \\
\text { fugitive soldiers...). }\end{array}$ \\
\hline Presumed & $\begin{array}{l}\text { Words indicating that the affiliation of one person to an illegal armed group or with an illegal } \\
\text { act is not confirmed (e.g. the person suspected to be a guerrilla fighter...). }\end{array}$ \\
\hline Noncommittal & $\begin{array}{l}\text { Terms that could be used to name any person or group, legal or not, armed or not (e.g. the } \\
\text { person, the man, the girl, the organization...). }\end{array}$ \\
\hline Nonexistent & $\begin{array}{l}\text { Expressions indicating that the person is not any more affiliated with an armed group or that } \\
\text { the armed group laid their weapons down (e.g. the ex-paramilitary member, paramilitaries } \\
\text { demobilized, ex-guerrilla fighter...). }\end{array}$ \\
\hline Denying a negative trait & $\begin{array}{l}\text { The cases classified in this category indicated that a representative of an armed group refused } \\
\text { one of the labels the group received (e.g. the ELN guerrilla is not a terrorist group). }\end{array}$ \\
\hline
\end{tabular}

In the second categorization, the expressions classified in the 'negative assessment' and 'presumed' categories were selected and categorized depending on the enunciator (journalist or source). Then the labels used by journalists were analysed depending on their discursive positioning (table 2): 


\section{Table 2. Discursive positioning of journalists regarding delegitimizing expressions}

\begin{tabular}{|c|l|}
\hline Discursive positioning & \multicolumn{1}{c|}{ Description } \\
\hline Detached positioning & $\begin{array}{l}\text { Expressions that journalists enunciate by quoting their sources and stressing that they did } \\
\text { not choose to label the armed group or the combatant this way or that the expression is } \\
\text { controversial (e.g. according to the governor, the so-called 'emergent groups'). }\end{array}$ \\
\hline $\begin{array}{c}\text { Partially detached } \\
\text { positioning }\end{array}$ & $\begin{array}{l}\text { In these cases, the linguistic tools used by journalists suggest that they are quoting their } \\
\text { sources, but it is not possible to assert that it was the source who enunciated the label to refer } \\
\text { an armed group (e.g. the ombudsman said that there are 25 new paramilitary groups involved } \\
\text { in drug trafficking...). }\end{array}$ \\
\hline Engaged positioning & $\begin{array}{l}\text { The expressions delegitimising an armed group are used by journalists without quoting any } \\
\text { source and without any indication that the expression is biased or controversial (e.g. the } \\
\text { FARC terrorist group is responsible for the attacks...). }\end{array}$ \\
\hline
\end{tabular}

\section{Results}

\section{Sources: plurality, balance and visibility}

To establish how present the war lexicon of the armed groups is in news, it is necessary to determine how present the armed groups are as sources in news reports. Despite the journalistic guidelines concerning the plurality of sources and their balance (CPB, 1990; Márquez González, 2003), figure 1 shows that 61 percent of the sources used by journalists ${ }^{6}$ in news reportage are official sources: the military (24 percent), the representatives of the government such as the President and the Minister of Defense (19 percent) and state representatives (18 percent). In addition, in only 29 percent of the news stories, journalists quote two or more sources. However, even in these cases the plurality of the points of view is not represented because in 93 percent of the 452 news items analysed, the different sources voiced the same or similar opinion. In sum, news concerning the armed conflict in Colombia is mostly unbalanced and partial.

\section{Visibility of the armed groups}

As can be seen from figure 1, the different armed groups - legal (the military) and illegal (paramilitary and guerrillas) - do not have the same

6 This paper refers only to journalists working for the national TV news programs. In fact, literature has shown that there is a great disparity between journalists who work for the national media and those who work for regional media organisations (Giraldo et al., 2003; Rincón and Ruíz, 2002). 


\section{Figure 1. Journalists' Sources (quoted or shown)}

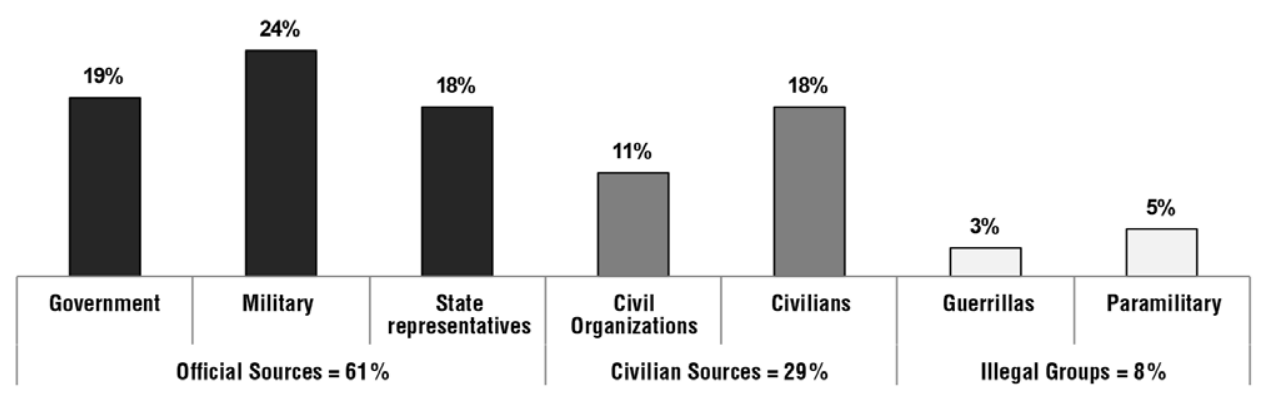

visibility in the media. The armed groups that journalists talk about most frequently are those whom they quote the least often as sources: 49 percent of news stories concern FARC guerrilla and, to a lesser extent, ELN guerrilla. In contrast, guerrilla representatives are quoted as sources in only 5 percent of the news stories and are shown speaking in only 1 percent of the news reports. In other words, guerrillas groups are mainly 'voiced' by their adversaries. This result is of an extreme importance because it means that national television news programs' audiences mainly knew about guerrillas from what their enemy said. Since the peace talk started, political leaders supporting peace talks have changed their discourse: FARC guerrillas became a legitimate political adversary. As a consequence, media has to deal with new discourses about an armed group who has been shown for a long period of time as a "terrorist" group with no political motivation. In this sense, the results of this study contribute to better understand the role played by media during peace negotiations (Serrano, 2014).

The situation with the paramilitary groups is similar. These are more often the subject of news (in 24 percent of the 452 news items) than sources: paramilitary representatives are quoted in 1 percent of the news reports and shown in 4 percent of them (see figure 2). Additionally, Colombian authorities, and then journalists, talk about the paramilitary groups as 'excombatants'. In fact, between 2003 and 2006 the government of former president Álvaro Uribe (2002-2006, 2006-2010) organized, in a controversial and criticized negotiation (CIJ, 2005), the disarming of the main confederation of paramilitary groups. That administration proudly claims that they 
managed to disarm more than 30.000 paramilitary combatants. ${ }^{7}$ Thus, the authorities presented the paramilitary groups who remained active as drug traffickers. In doing so, the government has hidden the ideologically extreme right-wing motivation of these groups. The only paramilitary representatives visible as sources in news reports are the representatives of the demobilized paramilitary fighters. In fact, the members of guerrillas and paramilitary groups were shown openly via the media only if they had laid down their weapons or were engaged in peace negotiations with the government, as is the case for representatives of FARC guerrillas since the peace talks started in October 2012. ${ }^{8}$

Unlike illegal groups, the representatives of the military are the only armed group who are more often quoted and shown as a source (17 percent) than mentioned in news as the main topic (13 percent-figure 2). Military representatives are also more often shown speaking (12 percent) than quoted as sources in news reports ( 5 percent). Of all the armed groups, the military has the most access to the media and thus more chances of imposing their war lexicon.

Figure 2. Visibility of the Armed Groups

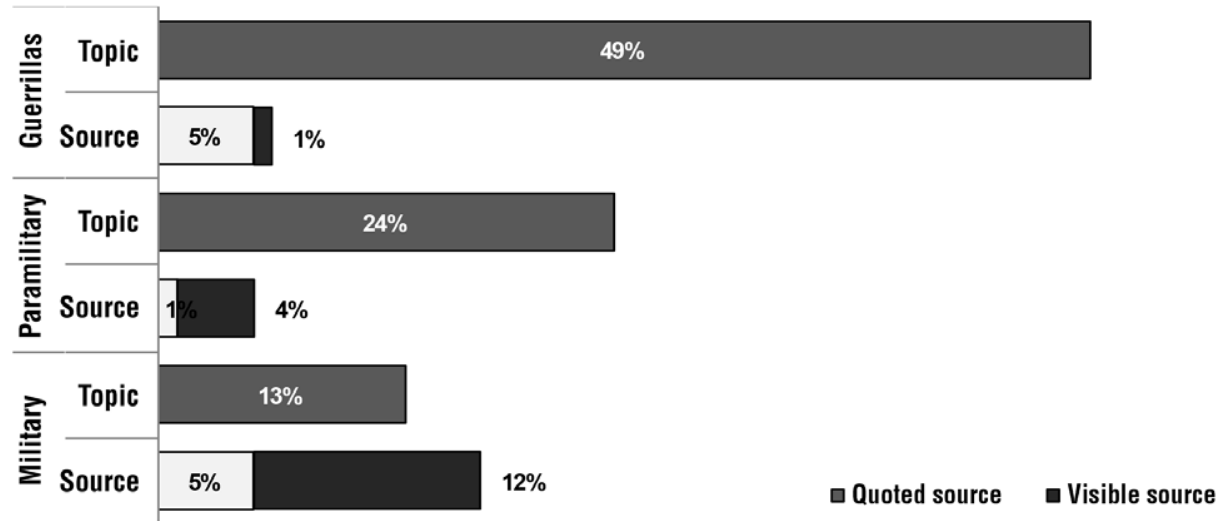

7 This number is also controversial because according to the confessions of some ex-fighters and current investigations, the government had staged many disarming ceremonies in order to show that its policies were successful.

8 Nevertheless, preliminary observations conducted in our current research project suggest that official sources (government representatives, government officials and political leaders) and especially the Colombian government negotiators are more visible than FARC negotiators (Serrano, 2014). 


\section{Naming the armed groups}

Even if journalists tend to use official sources more frequently and even if all the armed groups do not have the same chance of disseminating their strategic messages through the media, the analysis shows that journalists also tend to report news in a factual and descriptive style. Up to 90 percent of news reports follow the maxim of the five Ws (who, what, where, when, why - and how). Nevertheless, even when news seems to be factual and detached, it can still be biased. Actually, the qualitative analysis of the expressions used to refer to the armed groups illustrates the way in which the bias of news is hidden behind this factual and descriptive style and the way in which journalists participate in the war communication of armed groups.

Essentially, most of the labels used for the armed groups are used by journalists rather than by the groups' representatives: journalists used 90 percent of the 655 expressions referring the military. For guerrillas and paramilitary the percentage is 85 percent and 84 percent respectively. Moreover, for all the armed groups, the most common expressions are those that do not convey a negative or delegitimizing point of view. The most frequent labels are those that identify the armed groups by name (see figure 3 ).

\section{Figure 3. Naming the armed groups}

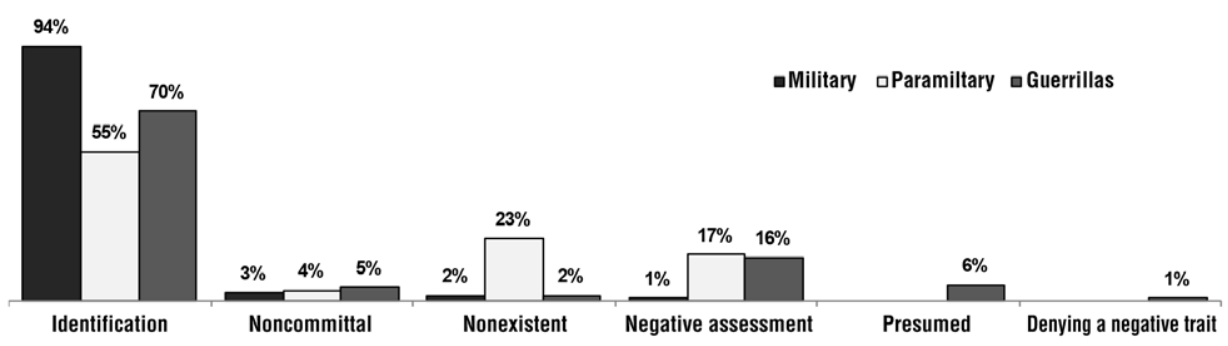

In this sense, bias in the labelling of the armed groups is not quantitatively significant. However, it is necessary to examine in detail the cases in which the war lexicon of the armed groups is adopted. For instance, the expressions classified in the 'nonexistent' category (figure 3) are more frequently used to refer to the paramilitary groups. As said before, one of the reasons for this is that after the paramilitary had laid down their weapons, it 
was strategic for the government to show and convince society that the demobilizations had been successful and that there were no longer any paramilitaries. Furthermore, the topic covered by 20 percent of these 452 news reports is related to the 'end of the paramilitaries', which is presented as a step towards peace in Colombia (Serrano, 2011).

Coincidentally, during the data collection for this study, the authorities began speaking of 'emergent groups involved in drug trafficking. This new label refers to the paramilitary fighters who have taken up arms again or who have not lain them down. The strategy of giving them another label asserts that they are not paramilitary but only drug traffickers. This finding suggests that further work is required to establish how this new expression and its synonyms, such as 'criminal gangs,' circulate in the media, how they are enunciated by journalists and to what extent they contribute to the war communications of the government.

As figure 3 shows, the illegal armed groups are almost exclusively labelled with expressions that defame them. No more than 1 percent of the expressions used to refer to the military are classified in the category 'negative assessment,' while 16 percent and 17 percent of the expressions referring to guerrillas and paramilitary groups respectively are in this category. In the few cases that military members are disapproved of, the expressions are not as explicit as those discrediting the illegal groups. Instead, the labels raise the notion that the military members are involved in trials: 'the 15 military members detained,' 'the fugitive soldiers,' 'the six military officers under investigation.' In doing so, these expressions designate the military as combatants having committed a crime, or being suspected of having done so, while emphasizing that the crimes are being investigated and/or the military members are being or are going to be punished.

In other words, at this level, the influence of the government and the military as main sources can be inferred. Not only are the expressions classified in the category 'negative assessment' rarely used to refer the military, but these expressions do not give any indication of the kind of crimes or offenses committed by the military officers. Even though journalists 
mentioned these crimes in the news reports, never is a military officer or a soldier labelled as a 'murderer' or a 'thief.' Concerning journalists' position in relation to expressions discrediting the military, figure 4 shows that 71 percent of these expressions are enunciated by journalists who do not indicate whether or not they are quoting their sources. In the other cases, journalists mention a source from whom they had obtained the information, but do not specify whether or not the expression used to label the military had been used by the sources.

In contrast, the way in which expressions delegitimise illegal armed groups is different. When paramilitaries are labelled with negative evaluative expressions, the focus is on their crimes. Thus journalists talk essentially about paramilitaries as 'murderers' on trial. In this case, most expressions (70 percent as shown in figure 4) are enunciated by journalists in an engaged manner, i.e. without quoting a source.

The case of guerrillas is an interesting example of the positioning of journalists. First, these groups are the main adversary of the military and the government, who have a privileged position as official sources. Second, FARC and ELN guerrillas are also the armed groups with the least access to the media. Nevertheless, contrary to what one might expect, journalists show a more detached positioning when they use expressions discrediting the guerrillas. From figure 4 it can be seen that the proportion of negative evaluative expressions used by journalists in a complete ( 33 percent) and partially (15 percent) detached manner is higher than when they refer to the military and paramilitary.

In other words, journalists show a less engaged discursive positioning when they name, in a negative way, the armed groups who have the least access to the media. It is rare for journalists to refer to guerrillas in an engaged manner with discrediting labels.

\section{The positioning of journalists: war communications hidden in the factuality of news}

Even though the analysis shows that journalists tend to enunciate in a detached manner the most controversial labels used for the armed groups, 


\section{Figure 4. Journalists' Discursive Positioning}

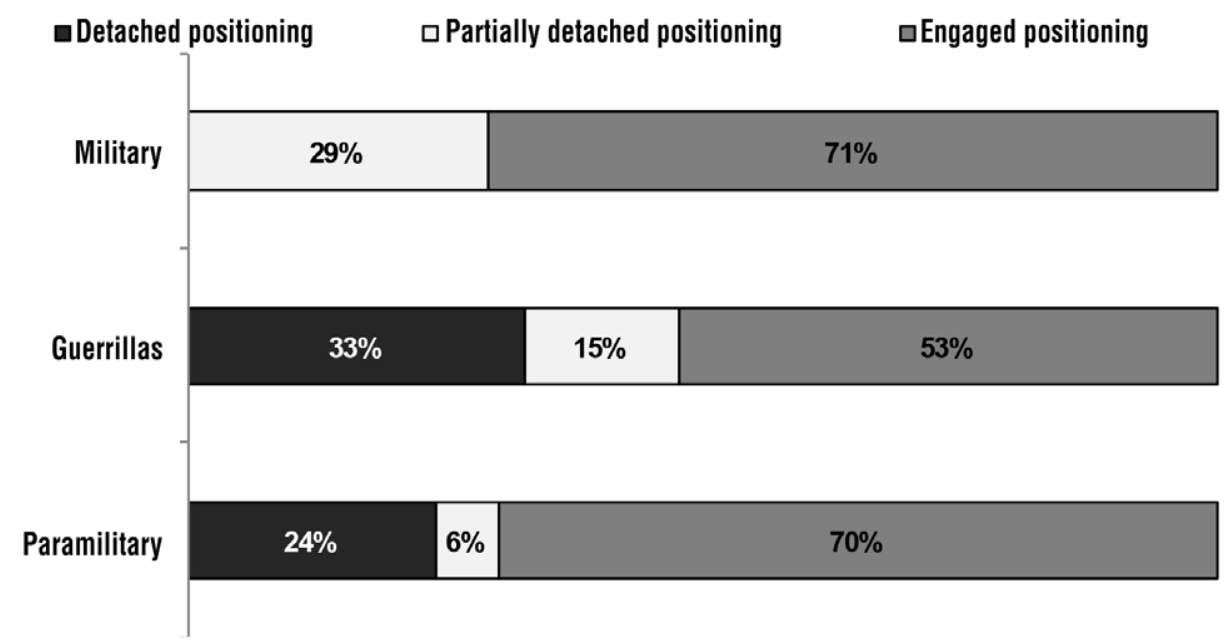

especially those who have less access to the media, the qualitative observations provide evidence to relativise the tendency. In certain polemic cases, journalists show a subtly biased discursive positioning. Let us consider the example of the expression 'terrorist.' The professional guidelines (Castro et al., 2005) prevent journalists from using this expression to refer to the armed groups because it corresponds to their own war lexicon. In the 452 news stories recorded for this research, the expression 'terrorist' appears 75 times. More than a half (45) are used to label illegal armed groups or their members. 23 of these 45 are enunciated by the sources and 22 directly by journalists. In this last case, journalists mainly indicate (18/22), that the expression had been used by a source, e.g. 'For the Danish justice system, FARC guerrilla is not a terrorist group. So was established by the Copenhagen court. ${ }^{9}$ When armed groups are characterized as 'terrorists,' journalists ensure that sources are quoted and that they do not use this controversial expression.

Nevertheless, one of the events covered by the news items recorded for this study suggests that one may look at these cases another way by considering the manner in which journalists quote sources. On 28 June 2007, FARC guerrilla had announced that 11 of the 12 members of the Valle del

9 Noticias Caracol, 13 December 2007. 
Cauca Departmental Assembly 'detained' by this guerrilla group since 2002 had died in crossfire. This tragic information had drawn the attention of the media that broadcast some segments of the speech given by the President. Among the four television news programs, Noticias RCN was the only one that selected the sequences where the President used the expression 'terrorist' most frequently:

\begin{abstract}
Mr. Álvaro Uribe: 'The government accuse the FARC terrorist group of murdering the representatives [...]. The death of the kidnapped [politicians] without any guerrilla fighter or soldier either assassinated or wounded shows that there has not been crossfire with the FARC terrorists. [...] The European emissaries, authorized by the government, had had a meeting with the terrorist Raúl Reyes during the third week of June [...]. We call on the international community to firmly condemn the FARC terrorist group.'
\end{abstract}

Even if journalists do not themselves use the word 'terrorist' to refer to the FARC guerrilla, Noticias RCN makes much more visible the sequences in which the official, and thus legitimated, source (in this case the President) appeared using it in order to discredit the enemy. In the sequences broadcasted by $\mathrm{CMr}^{\circ}$ and Noticias Caracol, the president was seen discrediting the FARC guerrilla as a 'terrorist' group on only one occasion. The sequences chosen by Telepaís did not include any part of the speech where the president says 'terrorist'.

A second case demonstrates that direct quotations (which are supposed to contribute to the objectivity of news) may be inaccurate in a sense that favours one of the parties to the conflict. Sometimes journalists enunciate the war lexicon of the armed groups in an engaged manner but suggest that they are exactly quoting the words said by their sources. This case is illustrated by the news stories broadcasted on 27 June 2007. That day, the four national television news programs announced that the ELN guerrilla, who were at that time in peace negotiations with the government, had committed itself to release all the 'people kidnapped' by this group. Without any exception, the four news reports talk of 'kidnapped' people:

Noticias Caracol: 'Pablo Beltrán, the spokesman of the ELN guerrilla, $[\ldots]$ pointed out that the ceasefire [...] would include the release of all the people the group keeps kidnapped. 
Telepaís: 'The commander of the ELN guerrilla, Pablo Beltrán, announced $[\ldots]$ that the agreement $[\ldots]$ includes the release of the people kidnapped'.

CM\&: 'The most significant step in the negotiations between the ELN guerrilla and the government happened today when the spokesman of this subversive group announced [...] the beginning of an agreement [which] means the return of the kidnapped people [...]'.

Noticias RCN: '[...] The ELN guerrilla [...] should release all the kidnapped people'.

By quoting this source, a spokesman of the ELN guerrilla, with verbs suggesting that journalists were relaying what he had said ('say', 'announce' and 'point out'), reporters give their reports a more objective appearance. $\mathrm{Ne}$ vertheless, by hearing the sequence that only Noticias RCN broadcast, including a part of Mr. Beltrán's speech, it is possible to note that the spokesman of the ELN guerrilla did not say that people were 'kidnapped', but that they were 'detained' by the ELN:

Pablo Beltrán: 'When the ELN signs the [agreement] it commits itself to release all the people detained by the group up to that moment'.

In fact, the words used in this case are of major importance for guerrilla groups and the military because of the legitimization associated with them. Between 1996 and 2012, hundreds of soldiers and tens of politicians were taken and kept captive mainly by the FARC, but also by ELN guerrillas. These guerrillas wanted to show their military capacity and to negotiate a 'humanitarian agreement' consisting of liberating the members of the military and politicians in exchange for guerrilla fighters in prison. In this context, the way in which the media talks about these members of the military and politicians is directly associated with the legitimacy given to guerrillas. While the military refers systematically to soldiers and politicians 'kidnapped by the guerrillas' in order to victimise the military combatants and thus delegitimise the guerrillas, the guerrillas refer to soldiers as 'prisoners of war' captured in combat and politicians as 'detained' people [ retenidos]. In doing so, they seek recognition as insurgent armed groups in a social and political internal armed conflict. This is the reason why the 
inaccuracy in the way in which journalists quote a source is not without repercussions in the war conducted by these armed groups. In this case, not only do journalists alter the discourse of their sources, they also do it by appropriating the war lexicon of the sources' adversary.

\section{Conclusions and Implications}

The purpose of this study was to analyse the discursive positioning of Colombian journalists working for four TV news programmes in relation to the war lexicon that the armed groups seek to impose and disseminate through the media. This study has found that journalists tend to use official sources more often when they report the news. This practice is not exclusive to the context of war. Previous research in journalism studies has shown that by using official sources, journalists protect themselves from criticism because these official sources are supposed to be more reliable (Berkowitz, 2009; Strömbäck and Nord, 2006). However, this journalistic routine has, in wartime, some implications that need to be considered. In the case analysed here, one of the official sources is the military that is directly involved in the armed conflict and has particular interests to defend. When using the military as a source journalists need to manage its war lexicon when reporting news according to their own guidelines.

However, one of the findings of this study is that even if most news reports are made in a factual style as professional guidelines stated ("Acuerdo por la discreción,” 1999; Castro et al., 2005; CPB, 1990; Márquez González, 2003), qualitative observations suggest that sometimes journalists transgress the 'objectivity' rules of accuracy and balance. The plurality and balance of sources are rarely practiced when journalists cover the armed conflict. In addition, inaccurate quotations were observed in news reports.

These findings raise the necessity of better understanding the work journalists do when they cover an internal armed conflict and when they have to deal with the pressure exerted by authorities and armed groups. In fact, the work of journalists in war is not only a matter for reporters but is also a matter of what sources do when they interact with them, as far as aiming to influence the agenda and framing of the conflict. Even if this seems 
an 'obvious' finding, as was noted at the beginning, the literature in Colombia continues to analyse the work of journalists in the coverage of this armed conflict only from a journalistic point of view, without considering the context of war and the limitations journalists face in applying their professional guidelines in wartimes. In this sense, this study's findings support two major arguments: (a) qualitative observations are needed to complete quantitative data in order to better understand the subtle bias of news reports; and (b) research in Colombia could benefit from integrating findings of scholars from different disciplines into their approaches. This study is particularly based on linguistics (for the analysis of issues related to naming), journalism studies (analysis of professional guidelines), political psychology and communication sciences (analysis of armed groups' war communication).

\section{References}

Acuerdo por la discreción. (1999). Retrieved from http://www.saladeprensa.org/art285.htm [accessed 26 March 2014].

Allan, S. \& Zelizer, B. (eds.). (2004). Reporting war: Journalism in wartime. London: Routledge.

Alzate, M., Durán, M. \& Sabucedo, J.M. (2009). Población civil y transformación constructiva de un conflicto armado interno: aplicación al caso colombiano. Universitas Psychologica, 8, 703-720.

Barbero, J.M. (1998). Medios, olvidos y desmemorias [WWW Document]. Retrieved from http://www.scribd.com/doc/92402291/MediosOlvidos-y-Desmemorias-JM-Barbero [accessed 26 March 2014].

Barbero, J.M. (2001). Cambios en el tejido cultural y massmediación de la política. In Bonilla, J.I., Patiño, G. (eds.), Comunicación y política. Viejos conflictos, nuevos desafíos (pp. 20-28). Bogotá: Centro Editorial Javeriano. 
Barón, L.F. (2001). La ilegitimidad frente al sectarismo. Representaciones sobre los conflictos en medios y audiencias de Irlanda del Norte y Colombia. Signo y Pensamiento, 20, 46-63.

Barreto, I., Borja, H., Serrano, Y. \& López, W. (2009). La legitimación como proceso en la violencia política, medios de comunicación y construcción de culturas de paz. Universitas Psychologica, 8, 737-748.

Berkowitz, D. (2009). Reporters and their sources. In Wahl-Jorgensen, K., Hanitzsch, T. (eds.), The handbook of journalism studies (pp. 102115). New York: Taylor \& Francis.

Bonilla, J.I. \& Patiño, G. (eds.). (2001). Comunicación y política: viejos conflictos, nuevos desafios. Bogotá: Centro Editorial Javeriano.

Bonilla, J.I. \& Tamayo, C.A. (2007). Violencias y medios de comunicación en América Latina: una cartografía para el análisis. Signo y Pensamiento, 26, 212-231.

Borja, H., Barreto, I., Sabucedo, J.M. \& López, W. (2008). Construcción del discurso deslegitimador del adversario: gobierno y paramilitarismo en Colombia. Universitas Pychologica, 7, 571-583.

Branca-Rosoff, S. (2007). Approche discursive de la nomination/dénomination. In Cislara, G., Guerin, O., Morin, K., Nee, E., Pagnier, T., Veniard, M. (eds.), L'acte de nommer. Une dynamique entre langue et discours (pp. 13-22). Paris: Presses Sorbonne Nouvelle.

Carlson, M. (2009). Dueling, dancing, or dominating? Journalists and their sources. Sociology Compass, 3, 526-542. doi:10.1111/j.17519020.2009.00219.x

Carruthers, S.L. (2011). The media at war. Palgrave: Macmillan. 
Castro, G., Villamizar, D., Restrepo, A. \& Guerrero, A. (2005). Diccionario para desarmar la palabra (2a ed.). Bogotá: Corporación Medios para la Paz, Planeta.

Chalaby, J.K. (1998). The invention of journalism. Basingstoke: Macmillan.

Charaudeau, P. (2009). Une éthique du discours médiatique est-elle possible ? Communication, 27(2), 51-74.

CIJ. (2005). Colombia: socavando el Estado de derecho y consolidando la impunidad. Genève: Comisión Internacional de Juristas.

CNTV. (2005). Informe del estudio general de medios de Colombia. Bogotá: Comisión Nacional de Televisión.

CNTV. (2009). Módulo de televisión. Estudio general de medios (EGM). Segunda ola 2008. Bogotá: Comisión Nacional de Televisión.

CNTV. (2011). Estudio general de medios (EGM) primera ola 2011. Bogotá: Comisión Nacional de Televisión.

Correa, A. (2001). Guerra y paz en directo: la información televisiva en tiempos de conflicto. In Bonilla, J.I., Patiño, G. (eds.), Comunicación y política. Viejos conflictos, nuevos desafíos (pp. 394-409). Bogotá: Centro Editorial Javeriano.

Correa, M. (2008). El lenguaje de los medios que intensifica el conflicto colombiano. Reflexión Política, 10, 106-113.

CPB. (1990). Código de ética y responsabilidad del periodista. Bogotá: Círculo de Periodistas de Bogotá.

Dayan, D. (2006). La terreur spectacle: terrorisme et télévision. Bruxelles: De Boeck/INA. 
El Tiempo. (2003). Conflicto armado y terrorismo. Manual de cubrimiento, el conflicto armado en las páginas de El Tiempo. Bogotá: Casa Editorial El Tiempo.

Entman, R. (1993). Framing: Toward clarification of a fractured paradigm. Journal of Communication, 43, 51-58.

Entman, R. (2010). Media framing biases and political power: Explaining slant in news of campaign 2008. Journalism, 11, 389-408. doi: $10.1177 / 1464884910367587$

Estrada, F. (2001).La retórica del paramilitarismo. Análisis Político, 44, 42-64.

Estrada, F. (2004). Las metáforas de una guerra perpetua. Estudios sobre pragmática del discurso en el conflicto armado colombiano. Medellín: Fondo Editorial Universidad EAFIT.

Flores, P. \& Crawford, L. (2001). El papel de los relatos noticiosos en la construcción de un proyecto comunicativo para la paz en Colombia. Diálogos de la Comunicación, 61, 46-55.

Giraldo, D., Roldán, I. \& Flórez, M.A. (2003). Periodistas, guerra y terrorismo. Bogotá: Escuela de Comunicación Social y Periodismo Universidad Sergio Arboleda, Planeta.

Hanitzsch, T. (2007). Deconstructing journalism culture: Toward a universal theory. Commun Theory, 17, 367-385. doi:10.1111/j.14682885.2007.00303.x

Hoskins, A., \& O’Loughlin, B. (2010). War and media. Cambridge: Polity Press.

Iyengar, S. (1991). Is anyone responsible ?: How television frames political issues. Chicago: Chicago Press. 
Keeble, R. (2007). The necessary spectacular "Victories”: New militarism, the mainstream media and the manufacture of the two gulf conflicts 1991 and 2003. In Maltby, S. \& Keeble, R. (eds.), Communicating war. Memory, media and military (pp. 200-212). Suffolk: Arima publishing.

López, F. (2000). Periodismo informativo y comunicación del conflicto armado y del proceso de paz en Colombia: consideraciones teóricas. Diálogos de la Comunicación, 59-60, 293-306.

López, F. (2001). Crisis de las representaciones política y mediática de los asuntos públicos en Colombia. In Bonilla Vélez, J.I. \& Jorge Iván, G. (eds.), Comunicación y política. Viejos conflictos, nuevos desafíos (pp. 50-67). Bogotá: Centro Editorial Javeriano.

López, F. (2002). Análisis sobre el derecho a la comunicación. Los medios y el proceso de paz, elementos para un balance necesario. Revista Aportes Andinos. Retrieved from http://www.uasb.edu.ec/padh/ revista4/articulos/fabiolopez.htm [accessed 26 March 2014].

López, F. (2003). Ética periodística, verdad noticiosa sobre el conflicto armado y reconciliación nacional en Colombia. Frankfurt: Presented at the Colombia, Caminos para Salir de la Violencia.

López, F. (2005). Aprendizajes y encrucijadas del periodismo. Entre la paz de Pastrana y la seguridad democrática de Uribe. Palabra Clave, 13, 7-45.

López, W. (2011). Medios de comunicación y construcción de culturas de paz. Santiago de Compostela: Universidad de Santiago de Compostela.

Maltby, S. (2010). Mediating peace? Military influencing activities in the balkans and Afghanistan. In Keeble, R., Tulloch, J., Zolloman, F. (eds.), Peace journalism, war and conflict resolution (pp. 223-238). New York: Peter Lang. 
Maltby, S. (2012). Military media management: Negotiating the "front" line in mediatized war. London, New York: Routledge.

Maltby, S. \& Keeble, R. (eds.). (2007). Communicating war: Memory, media and military. Suffolk: Arima Publishing.

Márquez González, E. (2003). Código para el cubrimiento del conflicto armado colombiano. Retrieved from http://www.unesco.org/new/ fileadmin/MULTIMEDIA/HQ/CI/CI/pdf/media_standards/ Codigo\%20para\%20el\%20cubrimiento\%20del\%20conflicto\%20 armado\%20colombiano.pdf [accessed 26 March 2014].

McQuail, D. (2010). McQuail's mass communication theory. London: SAGE Publications.

Moirand, S. (2009). Des façons de nommer "les jeunes" dans la presse quotidienne nationale. Adolescence, 70. doi:10.3917/ado.070.0907

MPP. (2006). Prensa, conflicto armado y región. Aprendizajes del diplomado Periodismo Responsable en el Conflicto Armado. Bogotá: Corporación Medios para la Paz.

PAN. (2004). El papel de las fuentes oficiales en la calidad del periodismo colombiano. Bogotá: Centro de Competencia en Comunicación para América Latina.

Reyes, A. (2011). Strategies of legitimization in political discourse: From words to actions. Discourse Society, 22, 781-807. doi:10.1177/0957926511419927

Rid, T. (2007, November-December). El nuevo desafío del Bundeswehr con los medios de comunicación. Military Review, Hispanoamericana, 70-77.

Rincón, O. \& Ruiz, M. (2002). Bajo todos los fuegos: los periodistas en el conflicto colombiano. Bogotá: Proyecto Antonio Nariño. 
Samouth, E. \& Serrano, Y. (2012). Nomination et enjeux politiques: nommer un conflit dans les médias colombiens et vénézuéliens. In Donot, M., Pordeus M., Discours politiques en Amérique Latine. Imaginaires et représentations (pp. 149-163). Paris: L'Harmattan.

Scheufele, D. (1999). Framing as a theory of media effects. Journal of Communication, 49, 103-122. doi:10.1111/j.1460-2466.1999. tb02784.x

Schudson, M. (2000). The power of news. Cambridge, Mass. [etc.]: Harvard University Press.

Schudson, M. \& Anderson, C. (2009). Objectivity, professionalism, and truth seeking in journalism. In Wahl-Jorgensen, K., Hanitzsch, T. (eds.), The handbook of journalism studies (pp. 88-101). New York: Taylor \& Francis.

Serrano, Y. (2011). Le conflit armé en Colombie dans les journaux télévisés nationaux. Mots. Les langages du politique, 97, 117-134.

Serrano, Y. (2014). Negotiating peace during war: How the Colombian news media contribute to peace or war when covering the armed conflict and the peace talks. Presented at the Media \& Governance in Latin America, The University of Sheffield.

Siblot, P. (2007). Nomination et point de vue : la composante déictique des catégories lexicales. In Cislaru, G., Guerin, O., Morin, K., Née, E., Pagnier, T., Veniard, M. (eds.), L'acte de nommer. Une dynamique entre langue et discours (pp. 25-38). Paris: Presses Sorbonne Nouvelle.

Strömbäck, J. \& Nord, L.W. (2006). Do politicians lead the tango? A study of the relationship between Swedish journalists and their political sources in the context of election campaigns. European Journal of Communication, 21, 147-164. doi:10.1177/0267323105064043 
Tamayo, C.A. \& Bonilla, J.I. (2005). El conflicto armado en pantalla. Noticieros, agendas y visibilidades. Controversia, 185, 21-49.

Torres, E. (2004). El periodismo en Colombia. Reflexiones sobre periodismo y comunicación en tiempos de guerra. Bogotá: Medios Para la Paz.

Tovar, C., Galindo, L.F. \& Guzmán, L. (2008). Desmovilización y convivencia local: el punto de vista de las comunidades receptoras. Revista Diversitas. Perspectivas en Psicología, 4, 305-317.

Tuchman, G. (1972). Objectivity as strategic ritual: An examination of newsmen's notions of objectivity. American Journal of Sociology, 77, 660-679.

Tumber, H. \& Webster, F. (2006). Journalists under fire information war and journalistic practices. London: Sage.

Veniard, M. (2011). Referring to parents in child protection reporting: A pragmatic-discursive study of a sensitive issue. Pragmatics and Society, 2, 301-327. 